J. Dairy Sci. 97:6271-6285

http://dx.doi.org/10.3168/jds.2014-8131

(C) American Dairy Science Association ${ }^{\circledR}, 2014$.

\title{
Quantitative evaluation of the relationship between dorsal wall length, sole thickness, and rotation of the distal phalanx in the bovine claw using computed tomography
}

\author{
T. Tsuka, ${ }^{1}$ Y. Murahata, K. Azuma, T. Osaki, N. Ito, Y. Okamoto, and T. Imagawa \\ Department of Veterinary Clinical Medicine, School of Veterinary Medicine, Faculty of Agriculture, Tottori University, Tottori, Japan, 680-8550
}

\section{ABSTRACT}

Computed tomography (CT) was performed on 800 untrimmed claws (400 inner claws and 400 outer claws) of 200 pairs of bovine hindlimbs to investigate the relationships between dorsal wall length and sole thickness, and between dorsal wall length and the relative rotation angle of distal phalanx-to-sole surface (S-D angle). Sole thickness was 3.8 and $4.0 \mathrm{~mm}$ at the apex of the inner claws and outer claws, respectively, with dorsal wall lengths $<70 \mathrm{~mm}$. These sole thickness values were less than the critical limit of $5 \mathrm{~mm}$, which is associated with a softer surface following thinning of the soles. A sole thickness of $5 \mathrm{~mm}$ at the apex was estimated to correlate with dorsal wall lengths of 72.1 and 72.7 $\mathrm{mm}$ for the inner and outer claws, respectively. Sole thickness was 6.1 and $6.4 \mathrm{~mm}$ at the apex of the inner and outer claws, respectively, with dorsal wall lengths of $75 \mathrm{~mm}$. These sole thickness values were less than the recommended sole thickness of $7 \mathrm{~mm}$ based on the protective function of the soles. A sole thickness $>7$ $\mathrm{mm}$ at the apex was estimated to correlate with a dorsal wall length of 79.8 and $78.4 \mathrm{~mm}$ for the inner and outer claws, respectively. The S-D angles were recorded as anteversions of $2.9^{\circ}$ and $4.7^{\circ}$ for the inner and outer claws, respectively, with a dorsal wall length of $75 \mathrm{~mm}$. These values indicate that the distal phalanx is likely to have rotated naturally forward toward the sole surface. The distal phalanx rotated backward to the sole surface at $3.2^{\circ}$ and $7.6^{\circ}$ for inner claws with dorsal wall lengths of $90-99$ and $\geq 100 \mathrm{~mm}$, respectively; and at $3.5^{\circ}$ for outer claws with a dorsal wall length $\geq 100 \mathrm{~mm}$. Dorsal wall lengths of 85.7 and $97.2 \mathrm{~mm}$ were estimated to correlate with a parallel positional relationship of the distal phalanx to the sole surface in the inner and outer claws, respectively.

Key words: computed tomography, bovine claw, relative angle of the distal phalanx to the sole surface, sole thickness, dorsal wall length

Received March 13, 2014.

Accepted June 23, 2014.

${ }^{1}$ Corresponding author: tsuka@muses.tottori-u.ac.jp

\section{INTRODUCTION}

Lameness inflicts considerable damage on affected cows, and can cause financial loss due to decreased milk production, increased loss of BW, death, culling, and decreased reproductive performance (Greenough and Vermunt, 1991). Foot trimming is recommended for prevention of claw diseases (Shearer and van Amstel, 2001). Toe overgrowths frequently occur in claws that have not been trimmed regularly, because of imbalance in growth and wear of the claw horn between the apex and the heel (Shearer and van Amstel, 2001). A long dorsal wall caused by lack of wear of the coronary horn will lead to rotation of the distal phalanx backward to the sole surface (Toussaint Raven, 1981; Blowey, 2005). Compression damage on the flexor tuberosity to the underlying corium leads to formation of sole ulcers (Toussaint Raven, 1981; Blowey, 2005).

Over-trimming is one of the main causes of thin soles, which is a suboptimal thickness of the weight-bearing surface of bovine claws (Shakespeare, 2009). Sole horn thickness is frequently $<5 \mathrm{~mm}$ in the softer sole surface, which is easily compressible by thumb pressure because thin soles induce exposure of the softer and immature horn (Kofler, 1999; van Amstel et al., 2003; Laven et al., 2012). A thin sole leads to increased flexibility, inducing sole compressive injury to the corium due to the flexor tuberosity of the distal phalanx (van Amstel et al., 2004). Moreover, thin soles are associated with thin sole-induced toe ulcers (TSTU) that occur adjacent to the white line in the apical portion of the weightbearing surface, called zones 1 and 2 (Greenough and Vermunt, 1991; Sanders et al., 2009). Thin sole-induced toe ulcer has been listed as the main cause of lameness, accounting for approximately $20 \%$ of cases (Sanders et al., 2009). Another probable factor in toe lesions is abnormal rotation of the distal phalanx forward to the sole surface, which is caused by over-trimming and laminitis-related forward sinking of the distal phalanx (Greenough et al., 1990; Kofler, 1999). This condition could lead to osteolytic changes and pathological fractures of the distal phalanx and ulcerations in the area of the apex (Kofler, 1999). 
Functional trimming is a common method to maintain the natural shape and function of the claws and to prevent over-trimming. The first step in functional trimming is to reduce the length of the dorsal wall (DW) to $75 \mathrm{~mm}$ or 3 in. (76.2 mm; Greenough et al., 1996; Shearer and van Amstel, 2001). The second step is to balance the weight-bearing surfaces to support equal force distribution between the inner and outer claws. The objective is to balance the weight-bearing surface of the outer claw with that of the inner claw (Shearer and van Amstel, 2001; van der Tol et al., 2004). The recommended DW length of $75 \mathrm{~mm}$ for functional trimming is a standard with a technical basis with the goal of maintaining a sole thickness of 5 to $7 \mathrm{~mm}$ (Shearer and van Amstel, 2001). However, a sole thickness $>7$ $\mathrm{mm}$ was recently recommended for maintaining the health of bovine claws (Toussaint Raven, 1989; van Amstel et al., 2004; Sanders et al., 2009; Laven et al., 2012). Therefore, additional margins to a DW length of $75 \mathrm{~mm}$ for functional trimming were recently recommended (Nuss and Paulus 2006). However, to date, there are few reports on sole thickness and rotation of the distal phalanx against the sole surface to provide a comprehensive view of the relationship between the shorter level $(<70 \mathrm{~mm})$ and the longer level $(>100 \mathrm{~mm})$ of the dorsal walls (van Amstel et al., 2003; Nuss and Paulus, 2006; Laven et al., 2012).

The application of computer tomography (CT) to bovine claws provides basic axial 2-dimensional (2D) images of objects and, through the reconstruction of consecutive scans, these images can be built up into 3-dimensional (3D) and 2D images that present views from every direction (Kofler et al., 1999; Raji et al., 2008; Tsuka et al., 2012). This function can provide mid-sagittal 2D images, which are the most useful sections for quantitative assessment of the internal structures of bovine claws (sole thickness and the relative rotation of the distal phalanx to the sole surface; Tsuka et al., 2012). The main purpose of the present study was to determine (1) which causative factors (e.g., age, inner/outer claws, floor type) influence the internal structures of bovine claws; (2) to what degree the variety of shapes of the untrimmed bovine claws (e.g., DW lengths, toe angles, and heel heights) correlates with the internal structure of bovine claws; (3) the optimal DW length corresponding to healthy internal structures (e.g., the recommended sole thickness of 7 $\mathrm{mm})$; (4) how the condition of the internal structure of bovine claws (sole thickness and relative rotation angle of distal phalanx-to-sole surface) correlates with DW lengths of $75 \mathrm{~mm}$ or 3 inches $(76.2 \mathrm{~mm})$; and (5) abnormalities of the internal structures of bovine claws with sole lesions occurring around the area of the apex and at the heel.

\section{MATERIALS AND METHODS}

Specimens comprised 200 pairs of hindlimbs that had been amputated at the fetlock. All hindlimbs were from lactating Holstein cows obtained from a slaughterhouse (Tottori Meat Inspection Center, Tottori, Japan). The age of the cattle ranged from 23 to 143 mo. The 200 cows were housed in 1 of 2 types of conditions: 123 were housed in tiestall barns ( $\mathbf{T}$ group; age: $58.2 \mathrm{mo}$ ), and 77 were housed in freestall barns or in indoor grouphousing (F group; age: $58.8 \mathrm{mo}$ ). Claw lesions were listed as interdigital dermatitis in 20 feet of 14 animals ( 8 in $\mathrm{T}$ group and 6 in $\mathrm{F}$ group); white line separations in 21 inner and 50 outer claws of 51 animals (36 in T group and 15 in $\mathrm{F}$ group); heel erosions in 27 inner and 47 outer claws of 35 animals ( 21 in T group and 14 in F group); and laminitis-related deformations (e.g., slipper claws and screw claws) in 23 animals (18 in $\mathrm{T}$ group and 5 in $\mathrm{F}$ group). External ulcers were not conspicuous in any of the 800 claws of the 200 cows. Information regarding clinical history (i.e., whether the animal had ever suffered claw problems or lameness) and trimming states (i.e., number of claw trimmings per year) was unavailable for all animals.

\section{CT Imaging Procedures}

The CT images were obtained with 2 types of CT devices. The first CT machine was a slip-ring scanner (Pronto SE, Hitachi Co. Ltd., Tokyo, Japan) and was used to observe 712 claws of 178 animals with the $\mathrm{x}$ ray tube operating at peak kilovoltage $(\mathrm{kVp})$ of 100 or 120 and a current of $100 \mathrm{~mA}$. The scanning was done at 2.5-mm slice thickness. The second $\mathrm{CT}$ machine was a 16-section multi-detector scanner (ECLOS, Hitachi Co. Ltd.) and was used to observe 88 claws of 22 animals with the x-ray tube operating at $120 \mathrm{kVp}$ and a current of $175 \mathrm{~mA}$. The scanning was done at 0.625 $\mathrm{mm}$ slice thickness. The specimen was placed on the table and oriented transverse to the scanning plane. Mid-sagittal 2D images were obtained by reconstructing the 3D images through an image analysis system (AZE Virtual Place, AZE Corp., Tokyo, Japan). Midsagittal 2D images were used to measure sole thickness and the relative angles of the distal phalanx to the sole surface.

\section{Quantitative Evaluations of CT Images}

Sole thicknesses were measured at 3 points on the mid-sagittal 2D CT images (Figure 1): point sole 1 (S1) was located on the virtual lines from the most apical margin of the distal phalanx to the sole surface; point sole 2 (S2) was a region perpendicular to the deepest 


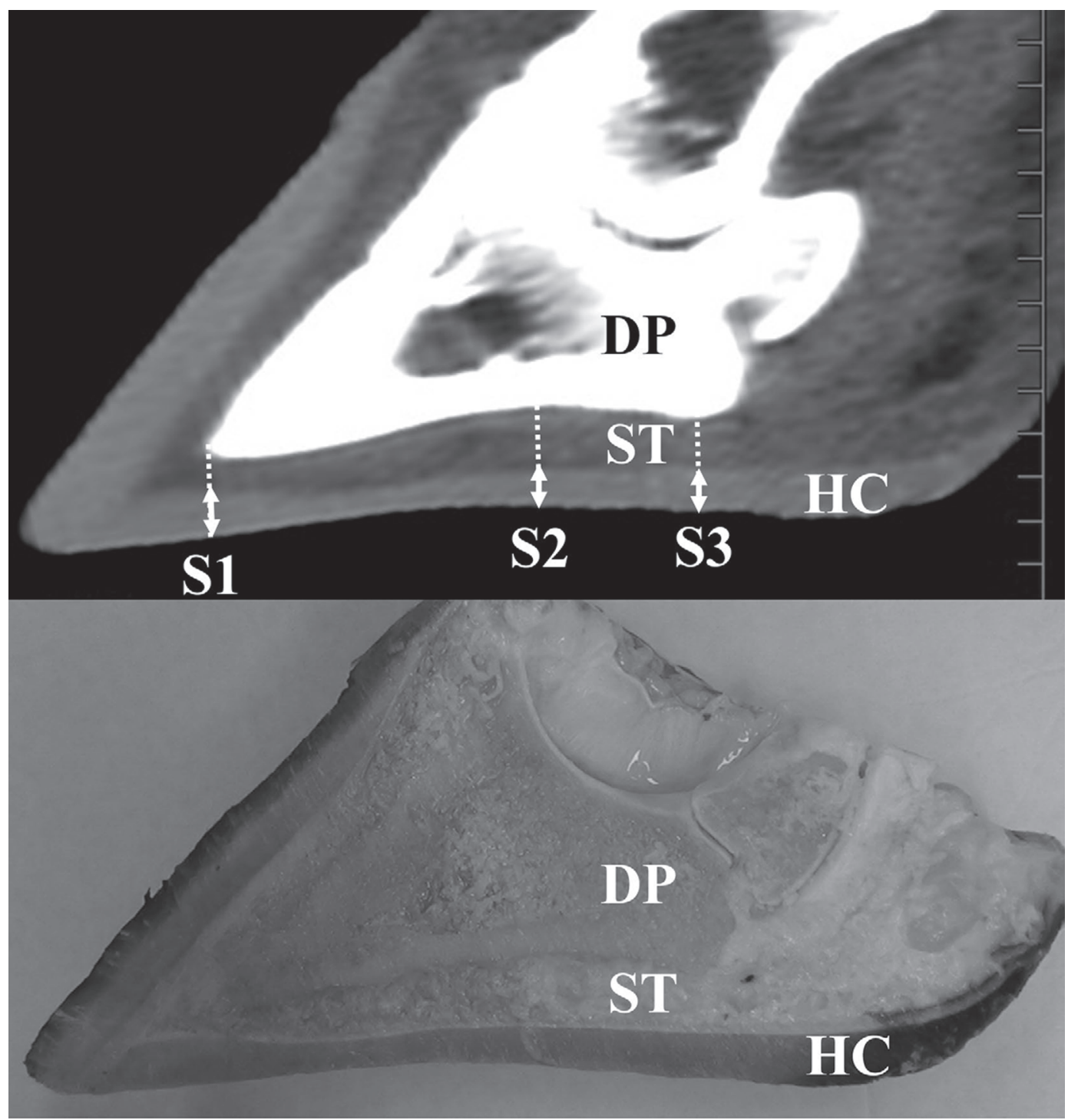

Figure 1. Basic mid-sagittal 2-dimensional computed tomographic (2D-CT) image and gross appearance used to measure sole thickness at points S1 (a region under the most apical margin of the distal phalanx), S2 (a region perpendicular to the deepest concavity of the ventral surface of the distal phalanx), and S3 (a region perpendicular to the flexor tuberosity). The image shows, respectively, the sole thickness of 5.1, 4.5 , and $4.6 \mathrm{~mm}$ at points $\mathrm{S} 1, \mathrm{~S} 2$, and $\mathrm{S} 3$ of the inner claw with a dorsal wall length of $75 \mathrm{~mm}$. DP = distal phalanx; ST = soft tissue layer; HC $=$ horn capsule. Scale $=5 \mathrm{~mm}$.

concavity of the ventral surface of the distal phalanx; and point sole 3 (S3) was a region perpendicular to the flexor tuberosity (Kofler et al., 1999).

The relative angle of the distal phalanx to the sole surface (S-D angle) was calculated from the angle between the virtual line along the apex to the flexor tuberosity in the distal phalanx and the sole surface (Figure 2A, B). Positive and negative values of S-D angles signify rotations of the distal phalanx forward to the sole surface (anteversion) and backward (retroversion), respectively.

\section{Observations of Internal Sole Lesions in the Claws Using CT Images}

Sole lesions inside the claws were grouped as follows: double soles or double heels in 21 inner and 35 outer claws of 39 animals (28 in T group and 11 in F group); sole horn-corium separations in 2 inner and 22 outer claws of 20 animals ( 8 in $\mathrm{T}$ group and 12 in $\mathrm{F}$ group). Sole damage was observed in zones 1 and 2 or zone 5 (toe damage) and in zones 4 and 6 (heel damage; Greenough and Vermunt, 1991). Toe damage was represented by 

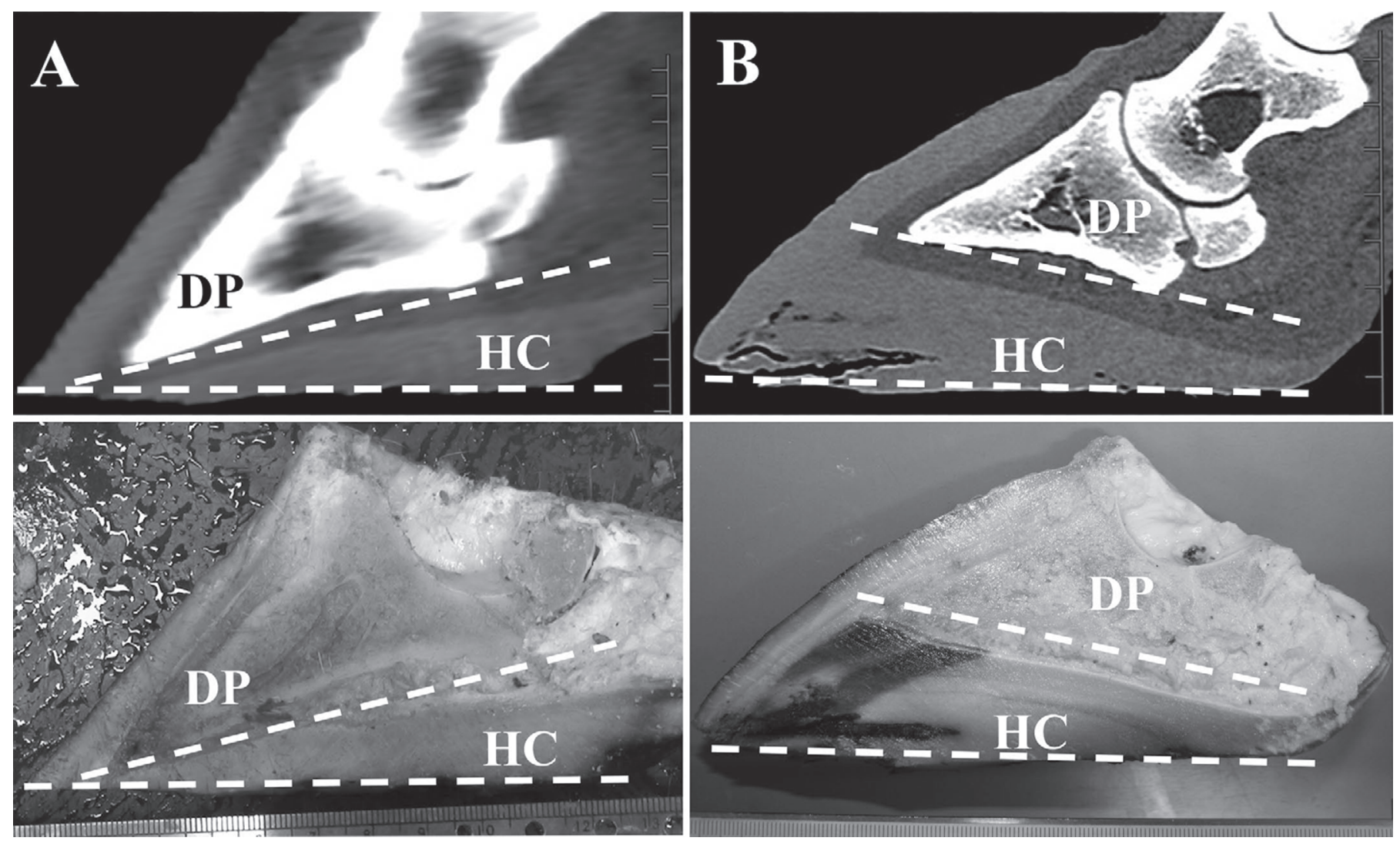

Figure 2. Basic mid-sagittal 2-dimensional computed tomographic (2D-CT) images and gross appearances used to measure the relative angle of the distal phalanx to the sole surface (S-D angle). The S-D angle was obtained by the relative angle between the virtual line along the apex to the flexor tuberosity in the distal phalanx, and the ventral surface of the sole capsule. (A) Positive values of S-D angles signify an anteversion of the distal phalanx to the sole surface. The image shows an S-D angle of $11.3^{\circ}$ in the outer claw with a dorsal wall (DW) length of $65 \mathrm{~mm}$. DP $=$ distal phalanx; $\mathrm{HC}=$ horn capsule. Scale $=5 \mathrm{~mm}$. (B) Negative values of S-D angles signify a retroversion of the distal phalanx to the sole surface. The image shows an S-D angle of $-10.1^{\circ}$ in the outer claw with a DW length of $102 \mathrm{~mm}$. DP $=$ distal phalanx; HC $=$ horn capsule. Scale $=10 \mathrm{~mm}$.

2 patterns: (1) the gray layers of the soles were thin, compressed, and partially perforated in relation to the downward protrusions of the dark gray layers of soft tissues, and white structures of the distal phalanxes on CT images (Figure 3A); (2) the black cracks run obliquely within the sole horns perpendicular to the apical margin of the distal phalanxes (Figure 3B). Black necrotic spots were sometimes observed within the soft tissues. Toe damage was observed in 2 inner and 13 outer claws of 13 animals ( 7 in $T$ group and 6 in $\mathrm{F}$ group). Heel damage was revealed by dark-colored cracks running obliquely, or necrotic spots, and partial perforations of the sole horns due to compressions from the flexor tuberosity of the distal phalanxes (Figure 4). Heel damage was observed in 6 inner and 28 outer claws of 26 animals (all in $\mathrm{T}$ group).

\section{Morphological Measurements of Claw Conformation, Sole Thickness, and S-D Angle}

Measurements of the claw horn were performed using 3 quantitative traits as described by Vermunt and
Greenough (1995): (1) toe angle (obtained from the slope of the dorsal border of the claw with respect to the sole surface); (2) DW length (obtained from the distance from the distal edge of the periople to the apex of the claw on the dorsal border); and (3) heel height (obtained from the vertical distance from the sole surface to the skin-horn junction). Dorsal wall length and heel height were measured grossly using a caliper. Toe angles were measured on mid-sagittal 2D CT images through an image analysis system (AZE Virtual Place, AZE Corp.

Soon after CT examination, sole thicknesses were measured on 248 claws from 62 pairs of hindlimbs. The claws were cut longitudinally along straight lines reaching from the middle of the apex to the middle of the heel on the sole surface using an electric hand saw.

The S-D angles were measured on the photos of 160 claws from 40 pairs of hindlimbs, which were cut longitudinally, by using the image analyzer software Image J (US National Institutes of Health, Bethesda, MD; http://rsb.info.nih.gov/ij/). 

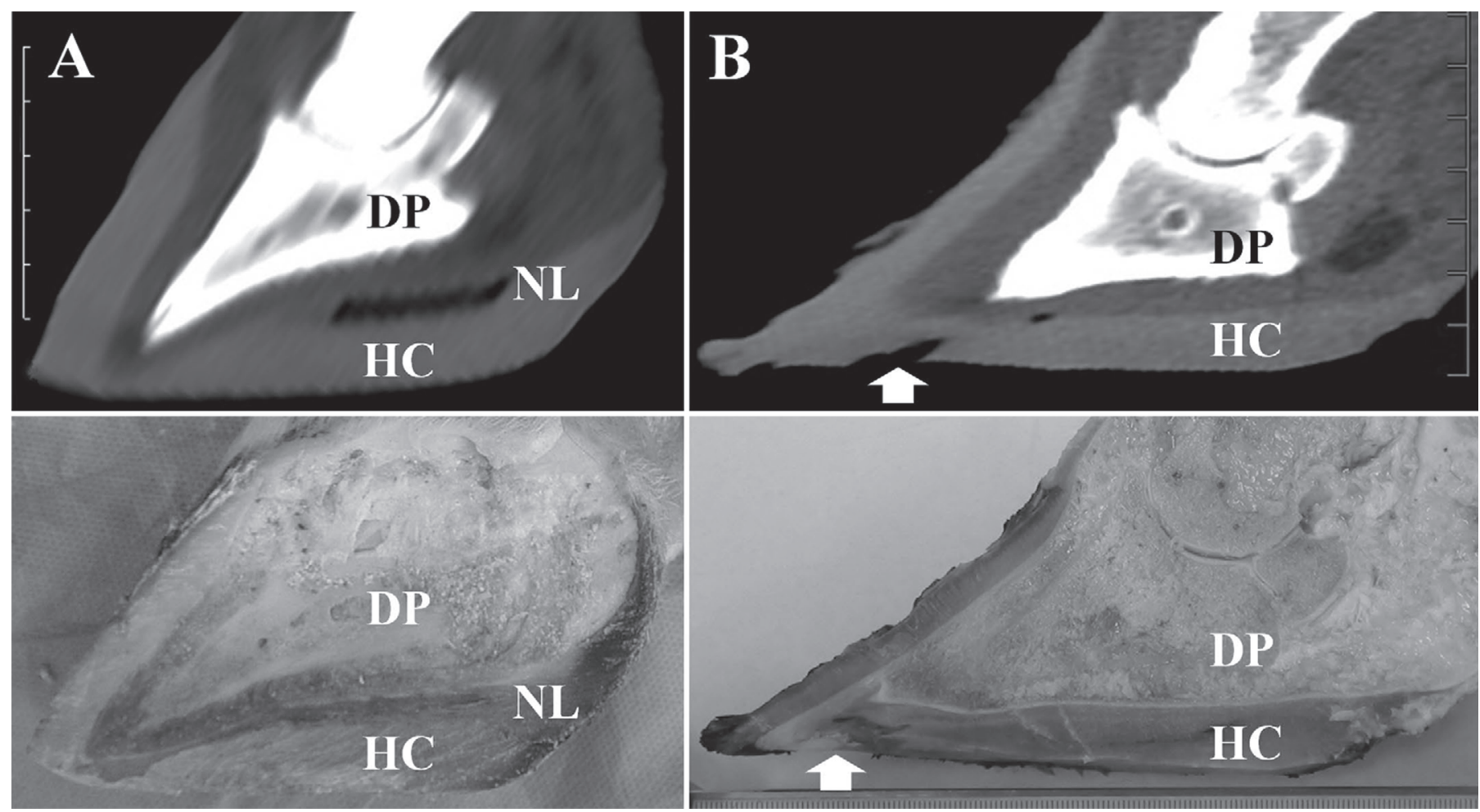

Figure 3. Mid-sagittal 2-dimensional computed tomographic (2D-CT) images and gross appearances of claws with sole lesions appearing within the areas of the apex. (A) The image shows the compression damage to the gray layers of the soles due to downward protrusions of the dark gray layer of the soft tissues, and the white structure of the distal phalanx within the area of the apex. An S-D angle (relative angle of the distal phalanx to the sole surface) of $14.6^{\circ}$ is recorded in the outer claw with a dorsal wall (DW) length of $66 \mathrm{~mm} . \mathrm{DP}=$ distal phalanx; HC $=$ horn capsule; NL = necrotic lesion. Scale $=10 \mathrm{~mm}$. (B) The image shows the black cracks running obliquely within the sole horns perpendicular to the apical margin of the distal phalanx, and the black necrotic spot within the soft tissues. An S-D angle of $6.2^{\circ}$ is recorded in the outer claw with a DW length of $78 \mathrm{~mm}$. DP $=$ distal phalanx; $\mathrm{HC}=$ horn capsule. Scale $=5 \mathrm{~mm}$.

\section{Statistical Analyses}

In total, 248 claws from 62 pairs of hindlimbs were used to investigate correlations between sole thickness (points S1, S2, and S3) measured grossly and that measured from CT images obtained from 40 pairs of specimens using CT machine 1 and 22 pairs of specimens using CT machine 2 . The correlation between the S-D angles measured grossly and those estimated from CT images was investigated for 160 claws from 40 pairs of hindlimbs (18 pairs using CT machine 1; 22 pairs using CT machine 2). Pearson correlation coefficients $(\mathrm{r})$ and $P$-values were used to compare the associations between the CT data and gross data.

The 3 claw conformation measurements (toe length, DW length, and heel height), sole thickness at each point (S1, S2, and S3), and S-D angles were subjected to statistical analysis. One-way ANOVA was performed to compare (1) among the left and right hindlimbs, and the total hindlimbs in each inner and outer claw group; (2) among $\mathrm{T}$ group, $\mathrm{F}$ group, and the total of the groups for each inner and outer claw group; and
(3) among inner and outer claws and the total claws. Symmetries between the left and right hindlimbs are represented by the relative ratios of the values for the left hindlimbs against the values for the right hindlimbs of the same animals (defined as $\mathbf{L}-\mathbf{R}$ ratio using the formula: left hindlimb data/right hindlimb data) for each inner and outer claw group. The relevance or relationships between these statistical objects and age was investigated using the Pearson correlation coefficients and $P$-values.

Statistical relationships between sole thickness and the 3 claw conformation measurements (toe length, DW length, and heel height) were investigated using Pearson correlation coefficients at each point (S1, S2, and S3) for the inner claws, the outer claws, and the total of the groups. Correlations between DW length and sole thickness at S1 were investigated using linear regression analysis in the inner and outer claw groups. Pearson correlation coefficients and $P$-values were calculated to reveal relationships between S-D angles and the 3 claw conformation measurements for the inner claws, the outer claws, and total groups. Correlations 

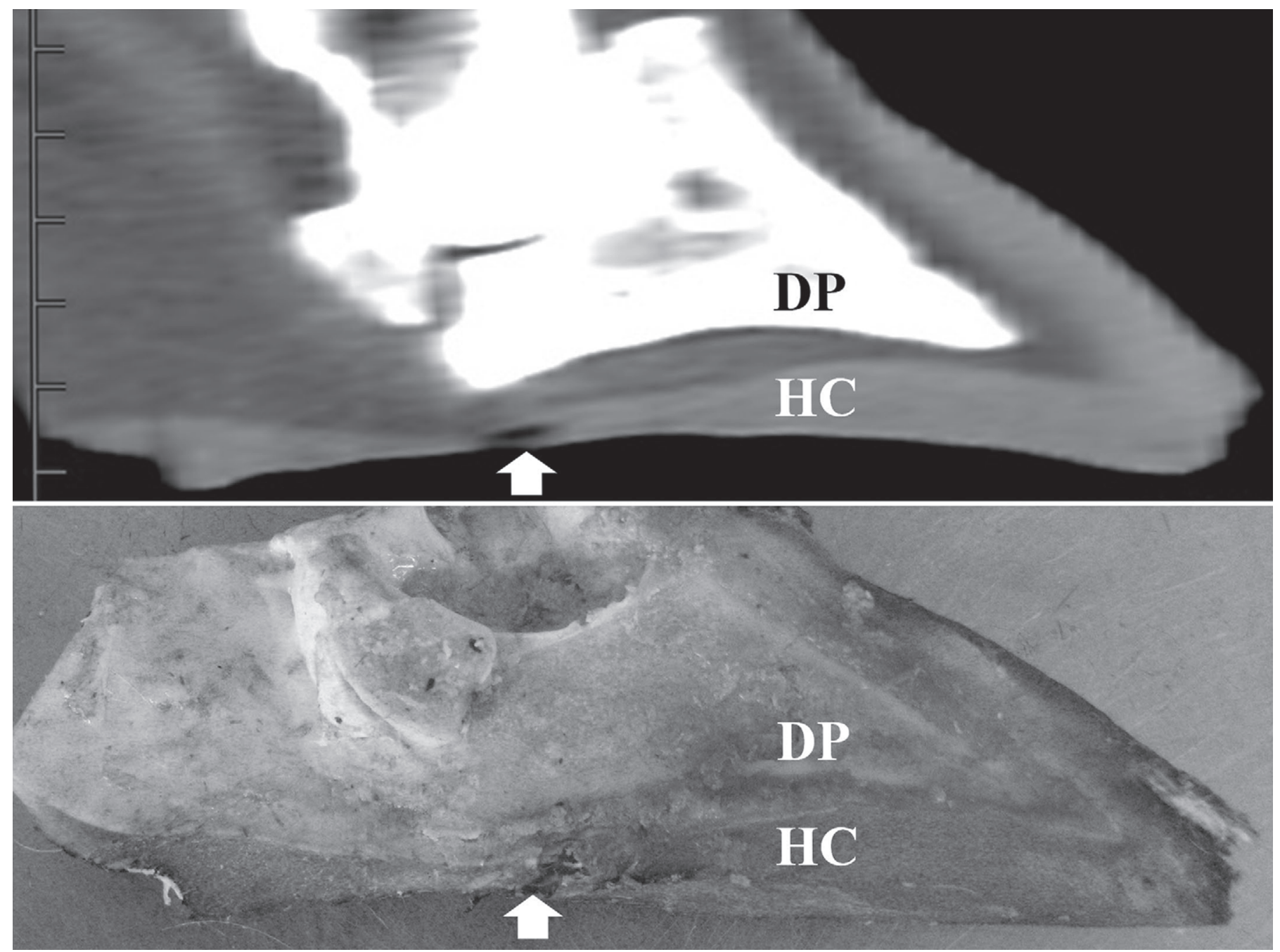

Figure 4. Mid-sagittal 2-dimensional computed tomographic (2D-CT) image and gross appearance of claws with sole lesions appearing within the areas of the heel. The image shows the black partial perforation of the sole horns due to compressions from the flexor tuberosity of the distal phalanx rotated backward. An S-D angle (relative angle of the distal phalanx to the sole surface) of $-3.3^{\circ}$ is recorded in the outer claw with a dorsal wall length of $77 \mathrm{~mm}$. DP $=$ distal phalanx; $\mathrm{HC}=$ horn capsule. Scale $=5 \mathrm{~mm}$.

between DW length and S-D angles were investigated using linear regression analysis for the inner and outer claw groups.

Sole thickness was measured at each point (S1, S2, and S3) in 800 claws by CT imaging. Sole thicknesses and S-D angles were investigated using the mean and standard error (SE) values in 5 groups based on the DW length: 800 claws (400 inner +400 outer claws) of 200 cows were categorized as follows: $72(41+31), 332$ $(171+161), 265(131+134), 92(41+51)$, and $39(16$ +23 ) claws with DW lengths $<70,70-79,80-89,90-99$, and $\geq 100 \mathrm{~mm}$, respectively. Analysis of variance was performed to compare among the $5 \mathrm{DW}$ length groups for sole thickness at each point (S1, S2, and S3), as well as S-D angles. Analysis of variance was performed for comparisons among the inner claws, outer claws, and combined groups in each of the $5 \mathrm{DW}$ length groups for sole thickness at each point (S1, S2, and S3), as well as for S-D angles.

Sole thickness and S-D angles were calculated for each inner and outer claw with a DW length of $75 \mathrm{~mm}$. A DW length of $75 \mathrm{~mm}$ was measured in 76 of 332 claws belonging to the $70-79 \mathrm{~mm}$ DW length group, comprising 40 inner claws and 36 outer claws. Within the $75 \mathrm{~mm}$ DW length group, these data were compared between the inner, outer, and combined claws using ANOVA.

The 3 claw conformation measurements, sole thickness (S1, S2, and S3), and S-D angles were calculated for the claws with toe damage $(\mathrm{n}=15)$ and heel damage $(\mathrm{n}=34)$. The data were then compared between the claws with or without sole damage (each case of toe 
damage or heel damage) and the combined claws using ANOVA.

The Scheffé test was used as a follow-up test for ANOVA. A $P$-value $<0.05$ was considered statistically significant.

\section{RESULTS}

We found significantly $(P<0.05)$ high correlations $(\mathrm{r}=0.98,0.98$, and 0.97$)$ between gross and CT measurements of sole thickness at points S1, S2, and S3, respectively. We also found significantly $(P<0.05)$ high correlations $(\mathrm{r}=0.94)$ between gross and $\mathrm{CT}$ measurements of S-D angles.

We detected no significant differences among the 3 claw conformation measurements, sole thickness (S1, $\mathrm{S} 2$, and S3), and S-D angle for each inner and outer claw between the left and right hindlimbs, or the L-R ratios (Tables 1 and 2). The DW lengths of the inner and outer claws of the T group were significantly $(P<$ $0.05)$ larger than those of the F group. Sole thicknesses at points $\mathrm{S} 1, \mathrm{~S} 2$, and $\mathrm{S} 3$ of the inner claws of $\mathrm{T}$ group were significantly $(P<0.05)$ smaller than those of $\mathrm{F}$ group. The S-D angles for the inner and outer claws of the $\mathrm{T}$ group were significantly $(P<0.05)$ smaller than those of the $\mathrm{F}$ group. In comparisons between inner and outer claws, the heel heights in the outer claws were significantly $(P<0.05)$ greater than those of the inner claws. The sole thickness (S1, S2, and S3) and S-D angle in the outer claws were significantly $(P<0.05)$ larger than those of the inner claws. Weak $(P<0.05)$ correlations were found between age and heel height, respectively, with values of 0.26 (0.21 and 0.33$)$ for the combined group (inner and outer claws); however, no correlation was found for toe angle or DW length, with values of $0.00(-0.01$ and 0.01$)$, and $-0.02(-0.02$ and -0.02 ) for the combined group (inner and outer claws). No significant correlation was found between age and sole thickness: $\mathrm{r}=-0.03(-0.02$ and -0.05$), 0.08(0.10$ and 0.06), and 0.04 (0.06 and 0.03) at points S1, S2, and $\mathrm{S} 3$ of the combined group (inner and outer claws). The Pearson correlation coefficients for age and S-D angle were weak $(P<0.05)$, with values of $0.20(0.19$ and 0.22 ) for the combined claws (inner and outer claws).

The Pearson correlation coefficients between DW length and sole thickness at point S1 $(0.57,0.72$, and 0.65 for the inner, outer, and combined claws, respectively) were higher than those at point S2 $(0.46,0.56$, and 0.52$)$ and point $\mathrm{S} 3(0.32,0.45$, and 0.40$)$, although all values were significant $(P<0.05)$. The Pearson correlation coefficients between heel height and sole thickness were 0.22 (0.12 and 0.27), 0.43 (0.31 and 0.46), and 0.47 (0.43 and 0.46), respectively, at points S1, $\mathrm{S} 2$, and S3 of the combined group (inner and outer claws). The values at points S2 and S3 were higher than at point $\mathrm{S} 1$, although all values were significant $(P<$ 0.05). The Pearson correlation coefficients between toe angle and sole thickness were $-0.26(-0.30$ and -0.27$)$, $-0.04(-0.05$ and -0.07$)$, and $0.08(0.09$ and 0.04$)$, respectively, at points $\mathrm{S} 1, \mathrm{~S} 2$, and $\mathrm{S} 3$ of the combined group (inner and outer claws). We detected weak $(P<$ $0.05)$ correlations between toe angle and sole thickness at point S1. Linear equations describing the relationships between DW length and sole thickness at point $\mathrm{S} 1$ were $\mathrm{y}=0.26 \mathrm{x}-13.75$ in the inner claw group; and $\mathrm{y}=0.35 \mathrm{x}-20.45$ in the outer claw group, where y rep-

Table 1. Mean (SE in parentheses) of 3 claw conformation measurements ${ }^{1}$ in the inner and outer claws of the left and right hindlimbs, and of a tiestall housing cow (T group), a freestall or indoor group-housing cow (F group), and the total cows grouped together

\begin{tabular}{|c|c|c|c|c|c|c|}
\hline \multirow[b]{2}{*}{ Item } & \multicolumn{3}{|c|}{ Inner claw } & \multicolumn{3}{|c|}{ Outer claw } \\
\hline & Toe angle $\left({ }^{\circ}\right)$ & $\begin{array}{l}\text { DW length } \\
(\mathrm{mm})\end{array}$ & $\begin{array}{l}\text { Heel height } \\
\quad(\mathrm{mm})\end{array}$ & Toe angle $\left(^{\circ}\right)$ & $\begin{array}{l}\text { DW length } \\
(\mathrm{mm})\end{array}$ & $\begin{array}{l}\text { Heel height } \\
(\mathrm{mm})\end{array}$ \\
\hline Left & $45.1(0.36)$ & $80.0(0.66)$ & $38.7(0.56)$ & $46.3(0.37)$ & $82.0(0.73)$ & $44.7(0.62)$ \\
\hline Right & $45.0(0.32)$ & $80.5(0.62)$ & $39.6(0.55)$ & $46.3(0.37)$ & $81.6(0.67)$ & $44.4(0.77)$ \\
\hline L-R ratio ${ }^{2}$ & $1.01(0.01)$ & $1.00(0.00)$ & $0.99(0.01)$ & $1.01(0.01)$ & $1.01(0.01)$ & $1.03(0.01)$ \\
\hline $\mathrm{T}$ group & $44.1(0.31)^{a}$ & $81.4(0.62)^{a}$ & $39.0(0.48)$ & $45.5(0.34)^{a}$ & $83.1(0.69)^{a}$ & $45.4(0.63)$ \\
\hline $\mathrm{F}$ group & $46.7(0.35)^{\mathrm{b}}$ & $78.6(0.60)^{\mathrm{b}}$ & $39.4(0.68)$ & $47.4(0.37)^{\mathrm{b}}$ & $79.7(0.62)^{\mathrm{b}}$ & $43.2(0.80)$ \\
\hline Total & $45.1(0.24)^{\mathrm{c}, \mathrm{d}}$ & $80.3(0.45)$ & $39.1(0.40)^{\mathrm{d}, \mathrm{f}}$ & $46.3(0.26)^{\mathrm{e}}$ & $81.8(0.50)$ & $44.5(0.50)^{\mathrm{e}, \mathrm{f}}$ \\
\hline Total claws & & & & $45.7(0.18)$ & $81.0(0.34)$ & $41.8(0.33)^{g}$ \\
\hline
\end{tabular}

${ }^{a-c}$ Data in the same column with different superscript letters are significantly different $(P<0.05)$.

${ }^{\mathrm{d}, \mathrm{e}}$ Data in the same row (inner claws vs. outer claws) with different superscript letters are significantly different $(P<0.05)$.

f,g Data in the inner and outer claw group are significantly different from those in the total claw group $(P<0.05)$.

${ }^{1}$ Toe angle is obtained from the slope of the dorsal border of the claw with respect to the sole surface; DW length is dorsal wall length obtained from the distance from the distal edge of the periople to the apex of the claw; heel height is obtained from the vertical distance from the sole surface to the skin-horn junction.

${ }^{2} \mathrm{~L}-\mathrm{R}$ ratio is the relative ratio of the values measured in the left hindlimb when the values measured in the same right hindlimb are defined as 1. 
Table 2. Mean (SE in parentheses) of sole thickness at points S1, S2, and S3, and S-D angles ${ }^{1}$ in the inner and outer claws of the left and right hindlimbs, and of a tiestall housing cow ( $\mathrm{T}$ group), a freestall housing or indoor group-housing cow (F group), and total cows grouped together

\begin{tabular}{|c|c|c|c|c|c|c|c|c|}
\hline \multirow{2}{*}{ Item } & \multicolumn{4}{|c|}{ Inner claw } & \multicolumn{4}{|c|}{ Outer claw } \\
\hline & \multicolumn{3}{|c|}{ Sole thickness $(\mathrm{mm})$} & $\begin{array}{c}\text { S-D } \\
\text { angle }\left({ }^{\circ}\right)\end{array}$ & \multicolumn{3}{|c|}{ Sole thickness $(\mathrm{mm})$} & $\begin{array}{c}\text { S-D } \\
\text { angle }\left(^{\circ}\right)\end{array}$ \\
\hline Left & $\begin{array}{c}7.71 \\
(0.31)\end{array}$ & $\begin{array}{c}9.51 \\
(0.29)\end{array}$ & $\begin{array}{c}9.75 \\
(0.25)\end{array}$ & $\begin{array}{c}1.33 \\
(0.29)\end{array}$ & $\begin{array}{c}8.35 \\
(0.35)\end{array}$ & $\begin{array}{l}10.99 \\
(0.35)\end{array}$ & $\begin{array}{l}11.59 \\
(0.34)\end{array}$ & $\begin{array}{c}3.90 \\
(0.30)\end{array}$ \\
\hline Right & $\begin{array}{l}7.20 \\
(0.28)\end{array}$ & $\begin{array}{c}9.38 \\
(0.29)\end{array}$ & $\begin{array}{c}9.88 \\
(0.26)\end{array}$ & $\begin{array}{c}1.40 \\
(0.26)\end{array}$ & $\begin{array}{c}8.44 \\
(0.34)\end{array}$ & $\begin{array}{l}11.00 \\
(0.36)\end{array}$ & $\begin{array}{l}11.29 \\
(0.33)\end{array}$ & $\begin{array}{c}3.70 \\
(0.27)\end{array}$ \\
\hline $\mathrm{T}$ group & $\begin{array}{c}7.01 \\
(0.26)^{\mathrm{a}}\end{array}$ & $\begin{array}{c}8.93 \\
(0.26)^{\mathrm{a}}\end{array}$ & $\begin{array}{c}9.27 \\
(0.23)^{\mathrm{a}}\end{array}$ & $\begin{array}{c}0.73 \\
(0.26)^{\mathrm{a}}\end{array}$ & $\begin{array}{c}8.29 \\
(0.32)\end{array}$ & $\begin{array}{l}10.79 \\
(0.33)\end{array}$ & $\begin{array}{l}11.13 \\
(0.32)\end{array}$ & $\begin{array}{l}3.40 \\
(0.27)^{\mathrm{a}}\end{array}$ \\
\hline F group & $\begin{array}{l}8.14 \\
(0.34)^{\mathrm{b}}\end{array}$ & $\begin{array}{l}10.26 \\
(0.34)^{\mathrm{b}}\end{array}$ & $\begin{array}{l}10.69 \\
(0.28)^{\mathrm{b}}\end{array}$ & $\begin{array}{l}2.38 \\
(0.25)^{\mathrm{b}}\end{array}$ & $\begin{array}{c}8.56 \\
(0.38)\end{array}$ & $\begin{array}{l}11.32 \\
(0.38)\end{array}$ & $\begin{array}{l}11.93 \\
(0.33)\end{array}$ & $\begin{array}{c}4.43 \\
(0.28)^{\mathrm{b}}\end{array}$ \\
\hline Total & $\begin{array}{l}7.44 \\
(0.21)^{\mathrm{c}}\end{array}$ & $\begin{array}{c}9.44 \\
(0.21)^{\mathrm{c}, \mathrm{e}}\end{array}$ & $\begin{array}{l}9.81 \\
(0.18)^{\mathrm{a}, \mathrm{c}, \mathrm{e}}\end{array}$ & $\begin{array}{l}1.36 \\
(0.19)^{\mathrm{a}, \mathrm{c}, \mathrm{e}}\end{array}$ & $\begin{array}{l}8.40 \\
(0.24)^{\mathrm{d}}\end{array}$ & $\begin{array}{l}10.99 \\
(0.25)^{\mathrm{d}, \mathrm{e}}\end{array}$ & $\begin{array}{l}11.44 \\
(0.24)^{\mathrm{d}, \mathrm{e}}\end{array}$ & $\begin{array}{l}3.80 \\
(0.20)^{\mathrm{d}, \mathrm{e}}\end{array}$ \\
\hline
\end{tabular}

\footnotetext{
${ }^{a, b}$ Data in the same column with different superscript letters are significantly different $(P<0.05)$.

${ }^{\mathrm{c}, \mathrm{d}}$ Data in the same row (inner claws vs. outer claws) with different superscript letters are significantly different $(P<0.05)$.

${ }^{e, f}$ Data in the inner and outer claw group are significantly different from those in the total claw group $(P<0.05) .{ }^{1} \mathrm{~S} 1$ is the point located on the virtual lines from the most apical margin of the distal phalanx to the sole surface; $\mathrm{S} 2$ is the point perpendicular to the deepest concavity of the ventral surface of the distal phalanx; S3 is the point perpendicular to the flexor tuberosity; S-D angle is the relative angle of the distal phalanx to the sole surface.

${ }^{2} \mathrm{~L}-\mathrm{R}$ ratio is the relative ratio of the values measured in the left hindlimb when the values in the same right hindlimb are defined as 1.
}

resents sole thickness and $\mathrm{x}$ is DW length. The Pearson correlation coefficients between DW lengths and S-D angles were moderate $(P<0.05)$, with values of -0.55 $(-0.66$ and -0.56$)$ for the combined claws (inner and outer claws). The Pearson correlation coefficients between S-D angle and heel height were weak $(P<0.05)$ with values of $0.26(0.19$ and 0.20$)$ for the combined claws (inner and outer claws). The Pearson correlation coefficients between toe angle and S-D angle were weak $(P<0.05)$ with values of $0.51(0.58$ and 0.44$)$ in the combined claws (inner and outer claws). The linear equations describing the relationship between DW length and S-D angle were $\mathrm{y}=-0.28 \mathrm{x}+23.99$ in the inner claw group (Figure $5 \mathrm{~A}$ ); and $\mathrm{y}=-0.23 \mathrm{x}+22.36$ in the outer claw group (Figure 5B), where y represents $\mathrm{S}-\mathrm{D}$ angle and $\mathrm{x}$ is DW length.

Sole thickness at points S1, S2, and S3 of the inner and outer claws with a DW length $<70 \mathrm{~mm}$ was significantly $(P<0.05)$ thinner than in the 70-79, 80-89, $90-99$, and $\geq 100 \mathrm{~mm}$ groups, except for nonsignificant differences between $<70$ and $70-79 \mathrm{~mm}$ groups at points S2 and S3 of the outer claws (Tables 3 and 4). Sole thickness at point S3 of the outer claws with DW lengths of $80-89,90-99$, and $\geq 100 \mathrm{~mm}$ were significantly $(P<0.05)$ larger than those of the inner claws.

The S-D angles were $4.21,2.55,1.48,-3.21$ and $-7.68^{\circ}$, and $6.79,4.72,4.48,0.63$, and $-3.48^{\circ}$ for the inner and outer claw groups, respectively, at DW lengths $<70,70-79,80-89,90-99$, and $\geq 100 \mathrm{~mm}$ (Table 4).
The S-D angles were recorded below an S-D angle of $0^{\circ}$ (which means a parallel positional relationship between the distal phalanx and the sole surface) for inner claws with DW lengths of 90-99 and $\geq 100 \mathrm{~mm}$, and for outer claws with DW length $\geq 100 \mathrm{~mm}$. The S-D angles of the outer claws were significantly $(P<0.05)$ larger than those of the inner claws for all 5 DW length groups.

Sole thickness at all points of the outer claws with a DW length of $75 \mathrm{~mm}$ tended to be larger than for the inner claws (Table 5 ). The S-D angle in the outer claw group $\left(4.73^{\circ}\right)$ was significantly $(P<0.05)$ larger than that of the inner claw group $\left(2.87^{\circ}\right)$. Heel height tended to be larger for the outer claws $(41.78 \mathrm{~mm})$ than for the inner claws $(38.03 \mathrm{~mm})$.

Sole thickness at point S1 was significantly $(P<0.05)$ less among claws with toe damage, than for claws without toe damage (Table 6 ). The S-D angle for the claws with toe damage was significantly $(P<0.05)$ larger than for the claws without toe damage. Heel height was significantly $(P<0.05)$ higher among the claws with heel damage than for the claws without heel damage. Sole thickness and S-D angles did not vary significantly among claws with and without heel damage, and the combined claws.

\section{DISCUSSION}

Computed tomography provides clear 2D images of bovine claws for visualization of the 3 layers comprising 

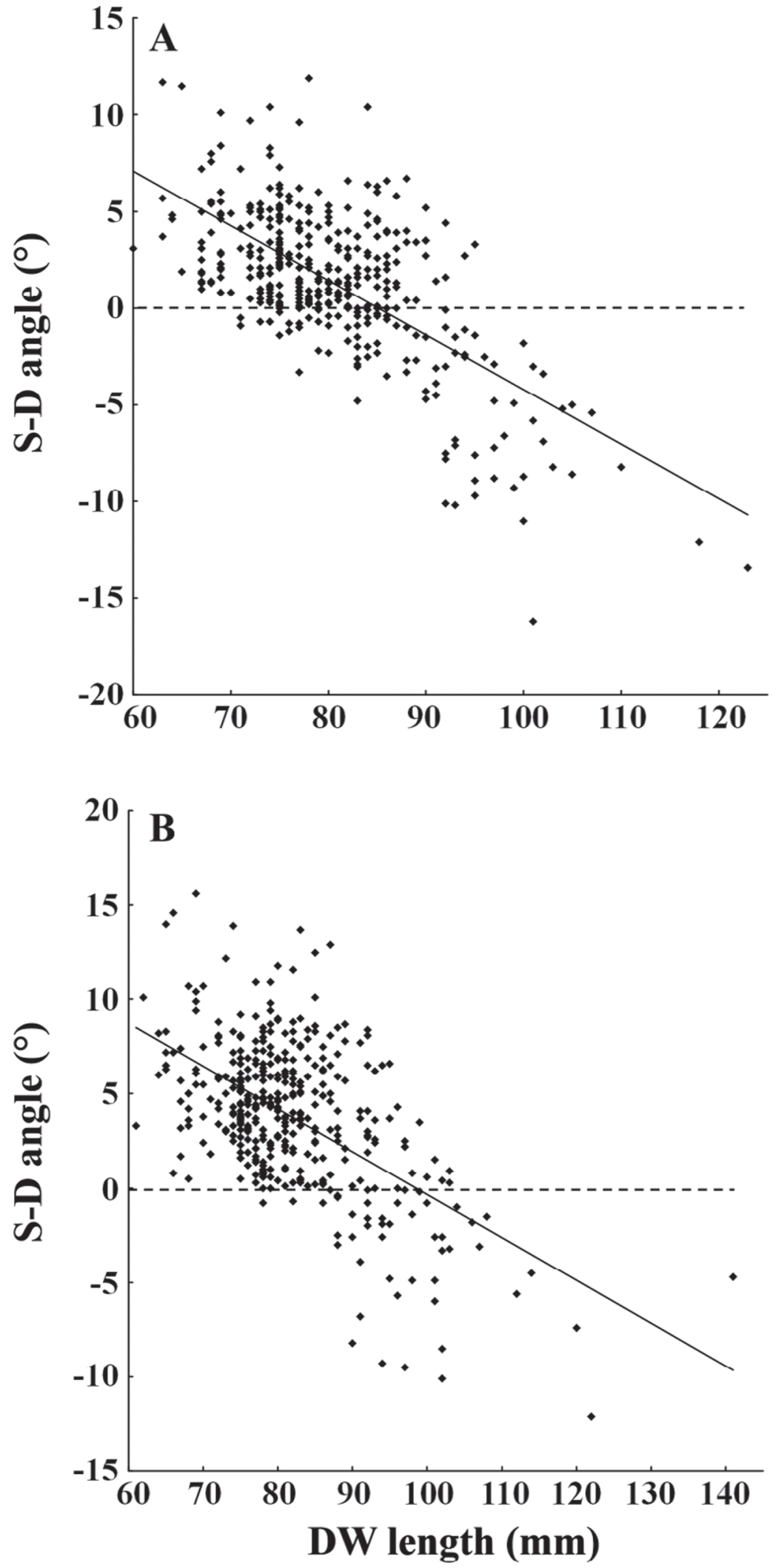

Figure 5. Correlation between dorsal wall (DW) length and S-D angle (relative angle of the distal phalanx to the sole surface) in the inner (A) and outer (B) claws. Broken lines represent an S-D angle of $0^{\circ}$. The DW lengths related to an S-D angle of $0^{\circ}$ are, respectively, 85.7 and 97.2 $\mathrm{mm}$ in the inner and outer claws according to the linear equations. 
Table 3. Mean (SE in parentheses) of sole thickness at points $\mathrm{S} 1$ and $\mathrm{S} 2^{1}$ in the inner and outer claws of $5 \mathrm{DW}$ length groups ( $<70,70-79,80-89,90-99$, and $\geq 100 \mathrm{~mm})$

\begin{tabular}{|c|c|c|c|c|c|c|}
\hline \multirow{2}{*}{$\begin{array}{l}\text { DW length }{ }^{2} \\
(\mathrm{~mm})\end{array}$} & \multicolumn{3}{|c|}{ Sole thickness at point $\mathrm{S} 1(\mathrm{~mm})$} & \multicolumn{3}{|c|}{ Sole thickness at point $\mathrm{S} 2(\mathrm{~mm})$} \\
\hline & Inner claws & Outer claws & Total & Inner claws & Outer claws & Total \\
\hline$<70$ & $3.80(0.34)^{\mathrm{a}}$ & $4.04(0.35)^{\mathrm{a}}$ & $3.90(0.24)^{\mathrm{a}}$ & $6.05(0.43)^{\mathrm{a}}$ & $7.27(0.51)^{\mathrm{a}}$ & $6.58(0.34)^{\mathrm{a}}$ \\
\hline $70-79$ & $6.35(0.18)^{\mathrm{b}}$ & $6.31(0.20)^{\mathrm{b}}$ & $6.33(0.13)^{\mathrm{b}}$ & $8.26(0.24)^{b}$ & $8.99(0.29)^{\mathrm{a}}$ & $8.61(0.19)^{\mathrm{b}}$ \\
\hline $80-89$ & $8.00(0.32)^{\mathrm{c}}$ & $8.72(0.28)^{\mathrm{c}}$ & $8.36(0.21)^{\mathrm{c}}$ & $10.68(0.37)^{\mathrm{c}}$ & $11.87(0.38)^{\mathrm{b}}$ & $11.28(0.27)^{\mathrm{c}}$ \\
\hline $90-99$ & $11.11(0.86)^{\mathrm{d}}$ & $11.80(0.69)^{\mathrm{d}}$ & $11.49(0.54)^{\mathrm{d}}$ & $12.20(0.61)^{\mathrm{d}}$ & $13.75(0.64)^{\mathrm{b}}$ & $13.06(0.45)^{\mathrm{d}}$ \\
\hline$\geq 100$ & $14.46(1.75)^{\mathrm{e}}$ & $19.45(1.40)^{\mathrm{e}}$ & $17.40(1.15)^{\mathrm{e}}$ & $13.46(1.30)^{\mathrm{d}, \mathrm{f}}$ & $18.82(1.40)^{\mathrm{c}, \mathrm{g}}$ & $16.62(1.06)^{\mathrm{e}}$ \\
\hline
\end{tabular}

${ }^{\mathrm{a} e}$ Data in the same column with different superscript letters are significantly different $(P<0.05)$.

${ }^{\mathrm{f}, \mathrm{g}}$ Data in the same row (inner claws vs. outer claws) with different superscript letters are significantly different $(P<0.05)$.

${ }^{1} \mathrm{~S} 1$ is the point located on the virtual lines from the most apical margin of the distal phalanx to the sole surface; S2 is the point perpendicular to the deepest concavity of the ventral surface of the distal phalanx.

${ }^{2} \mathrm{DW}$ length is dorsal wall length obtained from the distance from the distal edge of the periople to the apex of the claw.

the digital bones, the soft tissues, and the sole horn (Kofler et al., 1999; Raji et al., 2008; Tsuka et al., 2012). These 3 structures appear as white, dark gray, and bright gray zones, respectively, on CT images (Tsuka et al., 2012). The high contrast of CT images is useful for measurements of sole thickness and the relative angle between the ventral surface of the distal phalanx and the sole surface. In the present report, gross and CT measurements of sole thickness were highly and significantly correlated.

Quantitative CT analyses revealed that the increased thickness of the soles was significantly dependent on increased DW length. Correlations between DW length and sole horn thickness were higher overall in the area of the apex (point $\mathrm{S} 1 ; \mathrm{r}=0.65$ ) than in the middle region (point $\mathrm{S} 2 ; \mathrm{r}=0.52$ ), and the heel (point $\mathrm{S} 3 ; \mathrm{r}=$ $0.40)$. This indicates that measurements of DW lengths are more accurate in estimates of sole thickness when taken at the apex than at the middle region or the heel. The correlation between heel height and sole thickness was moderate in the area of the heel $(\mathrm{r}=0.47)$, although sole thickness in the area of the apex correlated less with heel height $(r=0.22)$. The increased height of the heel is likely associated with bone development in the flexor tuberosity and the thickened layer of soles (Toussaint Raven, 1981; Tsuka et al., 2012).

In the present report, sole thickness was 3.9, 6.6, and $7.4 \mathrm{~mm}$ at the apex, middle region, and heel, respectively, of claws with DW lengths $<70 \mathrm{~mm}$. These values were identical to previous data recording sole thickness of approximately 4.2 and $5.2 \mathrm{~mm}$ in the inner and outer claws, respectively, with DW lengths $<70$ $\mathrm{mm}$ (van Amstel et al., 2004). Sole thickness $<5 \mathrm{~mm}$ is associated with thin soles, which are easily compressible by thumb pressure (Kofler, 1999; van Amstel et al., 2003; Laven et al., 2012). Thin soles induce exposure of the softer and immature horn (van Amstel et al., 2004). In such animals, thin soles might have promoted TSTU if the animals had continued to live (Sanders et al., 2009); TSTU occurs adjacent to the white line in

Table 4. Mean (SE in parentheses) of sole thickness at points S3 and S-D angle ${ }^{1}$ in the inner and outer claws of 5 DW length groups $(<70,70-79,80-89,90-99$, and $\geq 100 \mathrm{~mm})$

\begin{tabular}{|c|c|c|c|c|c|c|}
\hline \multirow{2}{*}{$\begin{array}{l}\text { DW length }{ }^{2} \\
(\mathrm{~mm})\end{array}$} & \multicolumn{3}{|c|}{ Sole thickness at point S3 (mm) } & \multicolumn{3}{|c|}{ S-D angle $\left({ }^{\circ}\right)$} \\
\hline & Inner claw & Oute & Total & Inner claw & Outer claw & Total \\
\hline$<70$ & $7.15(0.46)^{\mathrm{a}}$ & $7.79(0.65)^{\mathrm{a}}$ & $7.42(0.38)^{\mathrm{a}}$ & $4.21(0.44)^{\mathrm{a}, \mathrm{f}}$ & $6.79(0.67)^{\mathrm{a}, \mathrm{g}}$ & $5.32(0.41)^{\mathrm{a}}$ \\
\hline $70-79$ & $9.09(0.26)^{\mathrm{b}}$ & $9.85(0.32)^{\mathrm{a}}$ & $9.46(0.20)^{b}$ & $2.55(0.19)^{\mathrm{b}, \mathrm{f}}$ & $4.72(0.21)^{\mathrm{b}, \mathrm{g}}$ & $3.60(0.15)^{\mathrm{b}, \mathrm{h}}$ \\
\hline $80-89$ & $10.94(0.32)^{\mathrm{c}, \mathrm{f}}$ & $12.53(0.39)^{\mathrm{b}, \mathrm{g}}$ & $11.75(0.26)^{\mathrm{c}}$ & $1.48(0.22)^{\mathrm{c}, \mathrm{f}}$ & $4.48(0.28)^{\mathrm{b}, \mathrm{g}}$ & $3.00(0.20)^{\mathrm{b}, \mathrm{h}}$ \\
\hline 90-99 & $11.16(0.48)^{\mathrm{c}, \mathrm{f}}$ & $13.65(0.62)^{\mathrm{b}, \mathrm{g}}$ & $12.54(0.43)^{\mathrm{c}}$ & $-3.21(0.69)^{\mathrm{d}, \mathrm{f}}$ & $0.63(0.61)^{c, g}$ & $-1.08(0.49)^{\mathrm{c}, \mathrm{h}}$ \\
\hline$\geq 100$ & $11.66(0.89)^{\mathrm{b}, \mathrm{f}}$ & $16.29(0.97)^{\mathrm{c}, \mathrm{g}}$ & $14.39(0.77)^{\mathrm{d}}$ & $-7.68(0.99)^{\mathrm{e}, \mathrm{f}}$ & $-3.48(0.75)^{\mathrm{d}, \mathrm{g}}$ & $-5.20(0.68)^{\mathrm{d}}$ \\
\hline
\end{tabular}

${ }^{\mathrm{a} e}$ Data in the same column with different superscript letters are significantly different $(P<0.05)$.

${ }^{\mathrm{f}} \mathrm{h}$ Data in the same row (inner claws vs. outer claws) with different superscript letters are significantly different $(P<0.05)$.

${ }^{1} \mathrm{~S} 3$ is the point perpendicular to the flexor tuberosity; S-D angle is the relative angle of the distal phalanx to the sole surface.

${ }^{2} \mathrm{DW}$ length $=$ dorsal wall length obtained from the distance from the distal edge of the periople to the apex of the claw. 
Table 5. Mean (SE in parentheses) of sole thickness, S-D angle, ${ }^{1}$ and heel height in inner and outer claws with a dorsal wall length of $75 \mathrm{~mm}$

\begin{tabular}{|c|c|c|c|c|c|}
\hline \multirow[b]{2}{*}{ Item } & \multicolumn{3}{|c|}{ Sole thickness $(\mathrm{mm})$} & \multirow{2}{*}{$\begin{array}{c}\text { S-D angle } \\
\left(\left(^{\circ}\right)\right.\end{array}$} & \multirow{2}{*}{$\begin{array}{l}\text { Heel height } \\
\quad(\mathrm{mm})\end{array}$} \\
\hline & S1 & $\mathrm{S} 2$ & S3 & & \\
\hline Inner claws & $6.05(0.29)$ & $8.15(0.38)$ & $9.32(0.45)$ & $2.87(0.34)^{\mathrm{a}}$ & $38.03(1.38)$ \\
\hline Outer claws & $6.42(0.38)$ & $9.06(0.37)$ & $10.24(0.49)$ & $4.73(0.34)^{\mathrm{b}}$ & $41.78(1.19)$ \\
\hline Total & $6.23(0.24)$ & $8.58(0.27)$ & $9.75(0.33)$ & $3.75(0.26)$ & $39.80(0.94)$ \\
\hline
\end{tabular}

${ }_{\mathrm{a}, \mathrm{b}}$ Data in the same column with different superscript letters are significantly different $(P<0.05)$.

${ }^{1} \mathrm{~S} 1$ is the point located on the virtual lines from the most apical margin of the distal phalanx to the sole surface; S2 is the point perpendicular to the deepest concavity of the ventral surface of the distal phalanx; S3 is the point perpendicular to the flexor tuberosity; S-D angle is the relative angle of the distal phalanx to the sole surface.

zones 1 and 2, and is one of the main causes of lameness in many dairy herds (Sanders et al., 2009; Shakespeare, 2009). According to the linear equations describing the relationship between DW length and sole horn thickness at the apex, sole thickness $>5 \mathrm{~mm}$ correlates with DW lengths of 72.1 and $72.7 \mathrm{~mm}$ in the inner and outer claws, respectively. This result suggests that a DW length of $73 \mathrm{~mm}$ may be the common borderline for over-trimming between the inner and outer claws.

Sole thickness was 6.1 and $6.4 \mathrm{~mm}$ at the toe of the inner and outer claws, respectively, for a DW length of 75 $\mathrm{mm}$, which is the recommended DW length when trimming the inner claw (Shearer and van Amstel, 2001). A DW length of $75 \mathrm{~mm}$ was associated with a sole thickness of 5 to $7 \mathrm{~mm}$ (Toussaint Raven, 1989; Shearer and van Amstel, 2001) and 4to $14 \mathrm{~mm}$ (mean $8.2 \mathrm{~mm}$; van Amstel et al., 2002). Moreover, in the report by van Amstel et al. (2003), the sole thickness in the inner and outer claws averaged $6.6 \mathrm{~mm}(4.4-9.8 \mathrm{~mm})$ and $7.2 \mathrm{~mm}$ (5.0-10.7 mm), respectively. The results of the current study are almost identical to previous data but less than the sole thickness of $7 \mathrm{~mm}$ required for the protective function of the soles (Toussaint Raven, 1989; van Amstel et al., 2003, 2004). According to the linear equations describing the relationship between DW length and sole thickness at the apex, a DW length of $76.2 \mathrm{~mm}$ (3 in.), another standard for functional trimming, is correlated with a sole thickness of 6.1 and $6.2 \mathrm{~mm}$ at point $\mathrm{S} 1$ of the inner and outer claws, respectively (Greenough et al., 1996). A DW length of $76.2 \mathrm{~mm}$ (3 in.) may not be enough to maintain the protective function of the soles (Toussaint Raven, 1989; van Amstel et al., 2003, 2004). It was recommended that trimmings for larger cows or bulls be extended beyond the base length of $3 \mathrm{in}$. by an appropriate length (i.e., $1 / 8$ to $1 / 4$ in.; Shearer, et al., 2005). A DW length of $82.5 \mathrm{~mm}$ (3.25 in.) is correlated with a sole thickness of 7.7 and $8.4 \mathrm{~mm}$ at the apex of the inner and outer claws, respectively, greater than the recommended sole thickness of $7 \mathrm{~mm}$ (Toussaint Raven, 1989; van Amstel et al., 2003, 2004; Shearer,

Table 6. Mean (SE in parentheses) of 3 claw conformation measurements, sole thickness at points S1, S2, and S3, and S-D angles ${ }^{1}$ in the claws with or without toe damages, and heel damages

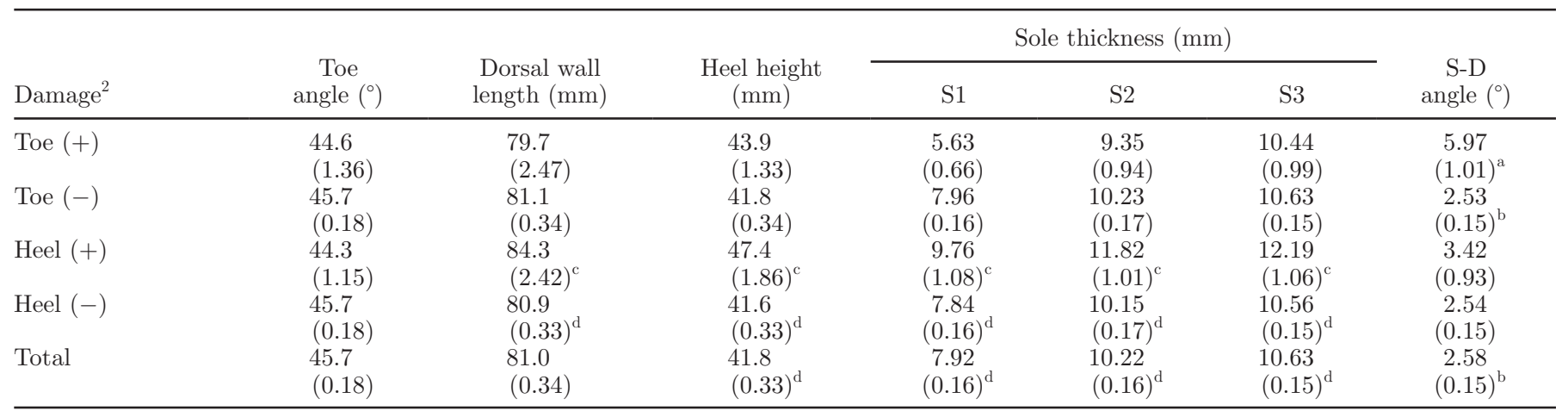

${ }^{\mathrm{a}-\mathrm{d}}$ Data in the same column with different superscript letters are significantly different $(P<0.05)$.

${ }^{1} \mathrm{~S} 1$ is the point located on the virtual lines from the most apical margin of the distal phalanx to the sole surface; S2 is the point perpendicular to the deepest concavity of the ventral surface of the distal phalanx; S3 is the point perpendicular to the flexor tuberosity; S-D angle is the relative angle of the distal phalanx to the sole surface.

${ }^{2}$ Toe $(+)=$ claws with toe damage, which are visualized within the soles near the apex on computed tomography $(\mathrm{CT})$ images; toe $(-)=$ claws without toe damage, and is the claw group to compete with toe $(+)$; heel $(+)=$ claws with heel damage, which are visualized within the soles near the heel on CT images; heel $(-)=$ claws without heel damage, and is the claw group to compete with heel $(+)$. 
et al., 2005). According to the same equations, a sole thickness $>7 \mathrm{~mm}$ was estimated to correlate with a DW length of 79.8 and $78.4 \mathrm{~mm}$ for the inner and outer claws, respectively. This supports the previous estimation that the addition of margins of $5 \mathrm{~mm}$ to the dorsal wall of $75 \mathrm{~mm}$ is recommended for functional trimming (Nuss and Paulus, 2006). Regarding functional trimming, over-trimming tends to occur easily within the outer claws during procedures of leveling, where the outer claw is trimmed to the weight-bearing surface, flush with the trimmed inner claw (Shearer and van Amstel, 2001; van der Tol et al., 2004). Trimming of the outer claws may need to be performed based on a DW length, as is trimming for the inner claws. The DW length is estimated to be $>79 \mathrm{~mm}$.

Sole thickness was larger in the area of the apex (average $17.4 \mathrm{~mm}$ ) than in the middle region (average 16.6 $\mathrm{mm}$ ) or heel region (average $14.4 \mathrm{~mm}$ ) in claws with a DW length $>100 \mathrm{~mm}$. Growth of the horn capsule advances faster in the area of the apex than in the area of the heel (Toussaint Raven, 1981). The DW length tends to increase with age and BW (Nuss and Paulus, 2006). Therefore, the overgrowth occurs primarily at the area of the apex if the claws do not receive continuous trimming (Toussaint Raven, 1981). Moreover, claw overgrowth could occur by accelerated horn production associated with laminitis due to an increased rate of horn growth rather than a simple lack of wear (Vermunt and Greenough, 1995). The condition leads to an elevation of the apex; backward rotation of the claw follows (Toussaint Raven, 1981; Blowey, 2005). This is believed to predispose to sole ulcers because of extra weight-bearing on the flexor tuberosity (Toussaint Raven, 1981; Blowey, 2005).

Overall, rotation of the distal phalanx to the sole surface was significantly dependent on DW length and heel height, with negative and positive correlations $(\mathrm{r}=-0.55$ and 0.26$)$, respectively. Therefore, a good rotation angle of the distal phalanx is likely to be achieved by management of the claws based on DW length. According to the linear equation describing the relationship between DW length and S-D angle in the inner claws, a DW length of $75 \mathrm{~mm}$ or $76.2 \mathrm{~mm}$ (3 in.) predicts natural anteversion of the distal phalanx to the sole surface with approximately $3.0^{\circ}$ or $2.7^{\circ}$ in the bovine claw. Within the soft tissues of the bovine claw, the digital cushion is present and arranged in a series of 3 parallel cylinders (abaxial, middle, and axial pads; Räber et al., 2004; van Amstel and Shearer, 2006). The longer axial digital cushion runs from the axial order of the heel bulb to the middle of the sole surface, and ends in the middle part of the distal phalanx (Räber et al., 2004; van Amstel and Shearer, 2006). Therefore, a layer of soft tissue is thinner under the apex of the distal phalanx than under the caudal parts of the distal phalanx. This is the possible anatomical cause for the natural anteversion of the distal phalanx to the sole surface. A DW length of $79 \mathrm{~mm}$, which was estimated to be associated with an adequate sole thickness of 7 $\mathrm{mm}$, correlated with an S-D angle of $1.6^{\circ}$ in the inner claws. Within the inner claws with this condition, mild anteversion is likely to be maintained. On the other hand, angles of rotation of the distal phalanx to the sole surface were greater in the outer claws than in the inner claws, compared with claws with the same DW length. Abnormal anteversions of the distal phalanx to the sole surface likely arise from the relatively lower position of the tip of the distal phalanx. The relatively lower position of the tip of the distal phalanx may be associated with 2 factors: (1) the lifting up of the caudal parts of the distal phalanx; and (2) a thinner sole in the area of the apex. The caudal parts of the distal phalanx are possibly lifted up due to the increased thickness of the soft tissue layers (the subcutis and the corium; Kofler et al., 1999; Lischer et al., 2002; Räber et al., 2004; Tsuka et al., 2012) and the larger height of the heel (Vermunt and Greenough, 1995). The thickness of the soft tissue layers in the outer claws $(7.3 \mathrm{~mm})$ was thicker than that in the inner claws $(6.6 \mathrm{~mm}$; Tsuka et al., 2012). The thickness of the soft tissue layers was also thicker in the outer claws than in the inner claws (Kofler et al., 1999; Lischer et al., 2002; Räber et al., 2004). This may be associated with the greater load in the sole and heel regions (Räber et al., 2004). A thinner sole in the area of the apex is related to a shorter DW due to imbalances between sole growth and wear, as well as over-trimming (Lischer et al., 2002; van Amstel et al., 2004; Laven et al., 2012). These factors are predicted to be identical with laminitis-related changes of the claw shapes (Vermunt and Greenough, 1995). Laminitis-related breakdown of the parallel relationship between the dorsal wall and dorsal surface of the distal phalanx occurs due to damage to the suspensory apparatus (Greenough et al., 1990; Nocek, 1997; Lischer et al., 2002). This condition advances rotations of the distal phalanxes forward and follows the occurrence of larger angles of the rotation of the distal phalanx to the sole surface, even if the DW lengths are extended in the laminitic claws. In the current study, these laminitisrelated changes were observed more frequently in the outer claws, than the inner claws.

In claws with a DW length $<70 \mathrm{~mm}$, the distal phalanx rotated forward to the sole surface with an average angle of $5.3^{\circ}$ (angles of $4.2^{\circ}$ and $6.8^{\circ}$ in the inner and outer claws, respectively). Significant $(P<0.05)$ differences between the inner and outer claws with a DW 
length $75 \mathrm{~mm}$ were observed in the S-D angles $\left(2.9^{\circ}\right.$ vs. $\left.4.7^{\circ}\right)$. The outer claws tended to have greater heights at the heel than the inner claws for a DW length 75 $\mathrm{mm}$. This leads to a lower location of the apex relative to the caudal parts of the distal phalanx within the horn capsule of the outer claws. Sole lesions appeared in areas of the apex in the claws with anteversions of the distal phalanx (average S-D angles of $6.0^{\circ}$ ). This supports the hypothesis that abnormal anteversions of the distal phalanx may induce injury of the corium and lead to ulcerations in the area of the apex (Kofler, 1999). Claws with a DW length $<70 \mathrm{~mm}$ and outer claws with a DW length of $75 \mathrm{~mm}$ may have increased risk of sole damage. The 2 types of sole damage related to a shorter DW (due to over-trimming and excess wear), which present on CT examinations, would be the precursor lesions of TSTU. The DW lengths 79 and $82.5 \mathrm{~mm}$ (3.25 in.) correlate with S-D angles of $4.2^{\circ}$ and $3.4^{\circ}$, respectively, in the outer claws (Toussaint Raven, 1989; van Amstel et al., 2003, 2004; Shearer et al., 2005). A DW length of $82.5 \mathrm{~mm}$ may be adequate for the outer claws based on the finding that an S-D angle of $3.4^{\circ}$ is close to the possible natural anteversion of $3.0^{\circ}$, which is estimated for inner claws with a DW length $75 \mathrm{~mm}$.

Rotation of the distal phalanx to the sole surface changed from forward to backward in the inner claws between the DW length 80-90 and 90-100 mm groups. In the outer claws, the distal phalanx rotated backward to the sole surface in the DW length $\geq 100 \mathrm{~mm}$ group. Retroversions of the distal phalanx to the sole surface linked to toe overgrowth provide extra weight-bearing on the flexor tuberosity to the underlying corium, and sole ulcers ensue (Blowey, 2005). In the linear equation describing the relationship between toe length and S-D angle, an S-D angle of $0^{\circ}$ means a parallel positional relationship of the distal phalanx to the sole surface. The value is important as the border between anteversion and retroversion of the distal phalanx, although it may not cause damage to the soles. The DW lengths related to an S-D angle of $0^{\circ}$ were 85.7 and $97.2 \mathrm{~mm}$ in the inner and outer claws, respectively, according to the linear equations. This result suggests that a DW length of $90 \mathrm{~mm}$ may be associated with anteversion of the distal phalanx in the outer claws but retroversion in the inner claws. This difference is strongly associated with frequent occurrences of laminitis-related breakdown of the parallel relationship between dorsal wall and dorsal surface of the distal phalanx in the outer claws, rather than in the inner claws. (Greenough et al., 1990; Nocek, 1997). Among claws with sole lesions in zones 4 and 6, (Greenough and Vermunt, 1991), severe retroversions of the distal phalanx were not typically found. The af- fected claws had greater heel heights compared with claws without such lesions. These lesions may have multiple causative factors, including bone development within the flexor tuberosity, derivations from heel lesions (e.g., heel erosions) as well as retroversions of the distal phalanx related to toe overgrowth and laminitis (Blowey, 2005; Tsuka et al., 2012).

Evaluations of a variety of causative factors other than DW length associated with changes in sole thickness, and rotations of the distal phalanx will be important for the maintenance of healthy claws and prevention of claw diseases. Thin sole occurrences are also likely to be related to age, feeding, floor condition (e.g., grooved concrete), lactation, and laminitis (Vermunt and Greenough, 1995; Nocek, 1997; Shakespeare, 2009; Laven et al., 2012). Claw overgrowth could also indicate an increased rate of horn growth rather than a simple lack of wear (Vermunt and Greenough, 1995). Accelerated horn production has been associated with feeding, housing conditions, and laminitis (Vermunt and Greenough, 1995). A previous report suggested that adequate DW length associated with good sole thickness may differ between heifers and older cows, because heifers have shorter toes than adult cows during their growing period (Laven et al., 2012). However, this was not evident from the present data, showing no correlation between age and DW length. On the other hand, a weak correlation $(\mathrm{r}=0.26 ; P<0.05)$ was found in the relationship between age and heel height. Age-related developments in heels are predicted to occur due to thickening changes in the soft tissues including the corium and bone development within the flexor tuberosity. A weak correlation $(\mathrm{r}=0.20 ; P<0.05)$ was found in the relationship between age and S-D angle, and no correlations were found for sole thickness. Inadequate DW length may lead to further forward rotations in older cows, which have greater heel heights. Mid- to late-lactating cows have an incidence of thin soles twice that of cows at other stages because of a faster rate of sole wear (Shakespeare, 2009). Second-lactation cows may be more affected than first-lactation lactations by carryover of insufficient sole condition due to excessive wear in the first lactation (Shakespeare, 2009). On the other hand, greater parity was associated with increased incidence rates for TSTU (Sanders et al., 2009). Further investigations of the relationship between CT values of bovine claws and lactation, as well as parity, will be needed for factorial analyses. Unfortunately, this information could not be obtained for the present report. The current study shows that thinner soles were significantly $(P<0.05)$ found in the inner and outer claws of tiestall-housed cows compared with freestall or indoor group-housed cows. This is likely associated 
with greater wear of soles in the claws of tiestall-housed cows. Lower levels of animal welfare exist in Japanese tiestall housing systems than in indoor group housing or freestall housing systems, based on the animal welfare index that includes the possibility of mobility (e.g., area per animal) and quality of flooring (Seo et al., 2007). Sole wear is predicted to be advanced by weakness in the soles and mechanical damage to the corium due to everyday wet flooring, difficulty in standing, and shorter times for lying down in environments typical of tiestall housing system (van Amstel et al., 2004). Moreover, laminitis, the causative factor for weakness of the soles, was predominantly observed as laminitis-related deformations of the claws in tiestall-housed cows. Further CT evaluations need to be performed using factorial analyses based on animal welfare conditions (e.g., area per animal and quality of flooring). Moreover, the present values and various estimations are applicable only to the claws of Holstein female cows. Independent standards will be needed for different breeds, both sexes, and for different levels of bovine productivity (e.g., dairy and beef) because of great differences in body mass among breeds and between sexes (Kratochvílová et al., 2002; Bene et al., 2007). Within the same breed, older cows tend to have larger body mass according to the growth curve (Kratochvílová et al., 2002). Agerelated risks may correlate with increased mechanical stress associated with increased body mass. Differences in breed, sex, body mass, and milk yield are expected to be traceable by comparison with the present data.

\section{CONCLUSIONS}

The present data indicate that DW lengths of 75 and $76.2 \mathrm{~mm}$ (3 in.), which are typically recommended for functional trimming, should not be applied to all claws. When the standard was applied to the outer claws, the distal phalanx rotated forward at a sharp angle (approximately $4.7^{\circ}$ ) to the dorsal face of the soles. This may lead to mechanical damage to the apex of the distal phalanx and the underlying corium. According to the relationship between DW length and S-D angle, 86 and $97 \mathrm{~mm}$ were estimated as the DW length related to the border between anteversions and retroversions of the distal phalanx in the inner and outer claws. According to the relationship between DW length and sole thickness, a DW length of $73 \mathrm{~mm}$ was estimated as the minimum for maintaining a sole thickness of $>5 \mathrm{~mm}$ in the area of the apex. Although sole thickness in the apex region of claws with DW lengths of 75 and 76.2 $\mathrm{mm}$ were measured at $>5 \mathrm{~mm}$, a DW length of $79 \mathrm{~mm}$ was needed to maintain a sole thickness of $7 \mathrm{~mm}$ based on the protective function of the soles. The application of $\mathrm{CT}$ to bovine claws will be meaningful for detecting how the addition of margins to the recommended DW length of $75 \mathrm{~mm}$ can adjust for various factors including the inner/outer claws, laminitis-related or age-related changes in bovine claws, and claw measurements in different breeds.

\section{ACKNOWLEDGMENTS}

We thank Hiroyuki Manabe, a foot trimmer, for advice during the preparation of the present report.

\section{REFERENCES}

Bene, S., B. Nagy, L. Nagy, B. Kiss, J. P. Polgár, and F. Szabó. 2007. Comparison of body measurements of beef cows of different breeds. Arch. Tierzucht. Dummerstorf 50:363-373.

Blowey, R. 2005. Preventing and treating lameness. Adv. Dairy Technol. 17:125-135.

Greenough, P. R., L. M. Schugel, and A. B. Johnson. 1996. Cattle lameness. Zinpro Corporation's Illustrated Handbook. Zinpro Co., Eden Prairie, MN.

Greenough, P. R., and J. J. Vermunt. 1991. Evaluation of subclinical laminitis in a dairy herd and observations on associated nutritional and management factors. Vet. Rec. 128:11-17.

Greenough, P. R., J. J. Vermunt, J. J. McKinnon, F. A. Fathy, P. A. Berg, and R. D. H. Cohen. 1990. Laminitis-like changes in the claws of feedlot cattle. Can. Vet. J. 31:202-208.

Kofler, J. 1999. Clinical study of toe ulcer and necrosis of the apex of the distal phalanx in 53 cattle. Vet. J. 157:139-147.

Kofler, J., P. Kübber, and W. Henninger. 1999. Ultrasonographic imaging and thickness measurement of the sole horn and the underlying soft tissue layer in bovine claws. Vet. J. 157:322-331.

Kratochvílová, M., L. Hyánková, H. Knížetová, J. Fiedler, and F. Urban. 2002. Growth curve analysis in cattle from early maturity and mature body size viewpoints. Czech J. Anim. Sci. 47:125-132.

Laven, L. J., J. K. Margerison, and R. A. Laven. 2012. Validation of a portable ultrasound machine for estimating sole thickness in dairy cattle in New Zealand. N. Z. Vet. J. 60:123-128.

Lischer, C. J., P. Ossent, M. Räber, and H. Geyer. 2002. Suspensory structures and supporting tissues of the third phalanx of cows and their relevance to the development of typical sole ulcers (Rusterholz ulcers). Vet. Rec. 151:694-698.

Nocek, J. E. 1997. Bovine acidosis: Implications on laminitis. J. Dairy Sci. 80:1005-1028.

Nuss, K., and N. Paulus. 2006. Measurements of claw dimensions in cows before and after functional trimming: A post-mortem study. Vet. J. 172:284-292.

Räber, M., C. H. J. Lischer, H. Geyer, and P. Ossent. 2004. The bovine digital cushion, a descriptive anatomical study. Vet. J. 167:258 264.

Raji, A. R., K. Sardari, and H. R. Mohammadi. 2008. Normal crosssectional anatomy of the bovine digit: Comparison of computed tomography and limb anatomy. Anat. Histol. Embryol. 37:188-191.

Sanders, A. H., J. K. Shearer, and A. De Vries. 2009. Seasonal incidence of lameness and risk factors associated with thin soles, white line disease, ulcers, and sole punctures in dairy cattle. J. Dairy Sci. 92:3165-3174

Seo, T., K. Date, T. Daigo, F. Kashiwamura, and S. Sato. 2007. Welfare assessment on Japanese dairy farms using the Animal Needs Index. Anim. Welf. 16:221-223.

Shakespeare, A. S. 2009. Inadequate thickness of the weight-bearing surface of claws in ruminants. J. S. Afr. Vet. Assoc. 80:247-253.

Shearer, J. K., and S. R. van Amstel. 2001. Functional and corrective claw trimming. Vet. Clin. North Am. Food Anim. Pract. $17: 53-72$. 
Shearer, J. K., S. R. van Amstel, and A. Gonzalez. 2005. Claw trimming. Pages 22-34 in Manual of Foot Care in Cattle. J. K. Shearer, S. R. van Amstel, and A. Gonzalez, ed. Hoard's Dairyman, Fort Atkinson, WI.

Toussaint Raven, E. 1981. Structure and functions of the claw. Pages 13-34 in Cattle Footcare and Claw Trimming. E. Toussaint Raven, ed. Terra Publishing Co., Arnhem, the Netherlands.

Toussaint Raven, E. 1989. Structure and Function. Pages 24-26 in Cattle Foot Care and Claw Trimming. E. Toussaint Raven, ed. Farming Press, Ipswich, UK.

Tsuka, T., K. Ooshita, A. Sugiyama, T. Osaki, Y. Okamoto, S. Minami, and T. Imagawa. 2012. Quantitative evaluation of bone development of the distal phalanx of the cow hind limb using computed tomography. J. Dairy Sci. 95:127-138.

van Amstel, S. R., F. L. Palin, B. W. Rorhbach, and J. K. Shearer. 2003. Ultrasound measurement of sole horn thickness in trimmed claws of dairy cows. J. Am. Vet. Med. Assoc. 223:492-494. van Amstel, S. R., F. L. Palin, J. K. Shearer, and B. F. Robinson. 2002. Anatomical measurement of sole thickness in cattle following application of two different trimming techniques. Bovine Pract. $36: 136-140$.

van Amstel, S. R., and J. K. Shearer. 2006. Review of pododermatitis circumscripta (ulceration of the sole) in dairy cows. J. Vet. Intern. Med. 20:805-811.

van Amstel, S. R., J. K. Shearer, and F. L. Palin. 2004. Moisture content, thickness, and lesions of sole horn associated with thin soles in dairy cattle. J. Dairy Sci. 87:757-763.

van der Tol, P. P., S. S. van der Beek, J. H. Metz, E. N. NoordhuizenStassen, W. Back, C. R. Braam, and W. A. Weijs. 2004. The effect of preventive trimming on weight bearing and force balance on the claws of dairy cattle. J. Dairy Sci. 87:1732-1738.

Vermunt, J. J., and P. R. Greenough. 1995. Structural characteristics of the bovine claw: Horn growth and wear, horn hardness and claw conformation. Br. Vet. J. 151:157-180. 